\title{
Potensi Tax Avoidance terhadap Peraturan Pemerintah Nomor 23 Tahun 2018 oleh Wajib Pajak Perseroan Terbatas
}

\author{
Suparna Wijaya*, Aditya Setiawan \\ ${ }^{1,2)}$ Politeknik Keuangan Negara STAN \\ sprnwijaya@pknstan.ac.id, 2301190069.adityasetiawan@ gmail.com
}

*Penulis korespondensi

Diajukan : 3 Juli 2021

Disetujui : 21 Juli 2021

Dipublikasikan : 1 Agustus 2021

\begin{abstract}
Micro, Small and Medium Enterprises (MSMEs) are businesses that have an important role in encouraging the Indonesian economy, so the government provides tax facilities by issuing Government Regulation No. 46 of 2013 as has been replaced by Government Regulation No. 23 of 2018. Government Regulation No. 23 of 2018 excludes corporate taxpayers in the form of CV and firms that provide services in connection with independent work, while Limited Liability Companies do not. This study aims to explain the potential for tax avoidance in Government Regulation Number 23 of 2018 that can be carried out by Limited Liability Company taxpayers regarding income related to independent work, as well as the impact and solutions of such tax avoidance actions. The method used in this research is descriptive qualitative. The results of the study indicate that taxpayers who will establish a business entity with the type of business related to independent work, can choose to establish a Limited Liability Company compared to a CV or firm, so that they can use the relatively lower rate of Government Regulation Number 23 of 2018. This of course has an impact on reducing tax revenues, so the Directorate General of Taxes needs to minimize the potential for tax avoidance through education, supervision, and regulatory improvements.
\end{abstract}

Keywords: bunching, income tax, SME's

\section{PENDAHULUAN}

Usaha Mikro, Kecil, dan Menengah (UMKM) merupakan usaha yang mempunyai peran penting dalam mendorong perekonomian Indonesia. Berdasarkan data Kementerian Koperasi dan Usaha Kecil dan Menengah, UMKM memberikan kontribusi sekitar 57\% sampai dengan 58\% terhadap total Produk Domestik Bruto (PDB) pada tahun 2012 sampai dengan 2018.

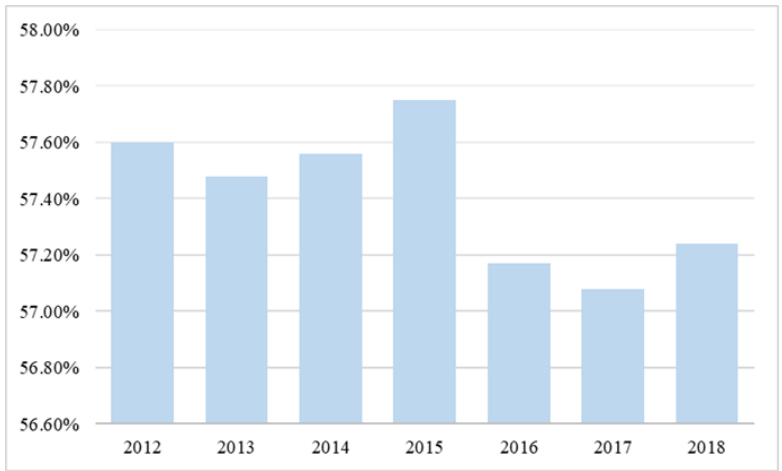

Gambar 1. Kontribusi UMKM terhadap PDB tahun 2012 s.d. 2018

Sumber: Diolah dari Kementerian Koperasi dan Usaha Kecil dan Menengah 
Selain itu, UMKM juga merupakan sektor usaha terbesar di Indonesia dengan proporsi sebesar 99,99\% dari total keseluruhan pelaku usaha, sehingga UMKM mempunyai peran yang sangat penting dalam penyerapan tenaga kerja. UMKM juga telah terbukti mampu untuk menunjukkan eksistensinya dalam perekonomian Indonesia dibandingkan dengan perusahaanperusahaan besar pada saat terjadi krisis moneter pada tahun 1998 (Profil Bisnis Usaha Mikro, Kecil Dan Menengah (UMKM), 2015).

Sebagaimana kegiatan usaha pada umumnya, pelaku UMKM juga harus memenuhi kewajiban perpajakannya, mulai dari mendaftarkan diri sebagai wajib pajak, menghitung pajak, menyetor pajak, dan melaporkan pajaknya. Menurut Soemitro (1979, dikutip dalam Mustaqiem, 2014), pajak adalah iuran rakyat kepada negara berdasarkan undang-undang (dapat dipaksakan) tanpa memperoleh timbal balik (kontra prestasi) secara langsung, yang digunakan oleh negara untuk pengeluaran umum maupun sebagai pencegah atau pendorong tujuan lain. Pendapat serupa juga dijelaskan oleh Adriani (2012, dikutip dalam Widyana, 2018). Sedangkan Soemahamidjaja (1993, dikutip dalam Widyana, 2018), pajak merupakan iuran wajib berbentuk uang ataupun barang yang dipungut penguasa dengan berdasar pada norma-norma hukum, untuk menutup biaya produksi barang maupun jasa guna mencapai kesejahteraan umum.

Di Indonesia, pajak merupakan sumber penerimaan negara yang paling utama dalam struktur Anggaran Pendapatan dan Belanja Negara (APBN). Dari tahun ke tahun, persentase penerimaan pajak terhadap total pendapatan dalam APBN terus mengalami peningkatan. Terhitung sejak tahun 2015 hingga 2019, persentase penerimaan dari sektor perpajakan terhadap total keseluruhan penerimaan negara terus tumbuh dari 69,2\% sampai dengan 82,5\% (Anwar et al., 2019). Hal tersebut membuktikan bahwa pajak mempunyai peranan yang sangat penting bagi keberlangsungan negara. Dari berbagai jenis pajak, Pajak Penghasilan menjadi salah satu jenis pajak yang paling banyak diterapkan di berbagai negara, salah satunya adalah Indonesia (Darussalam et al., 2020).

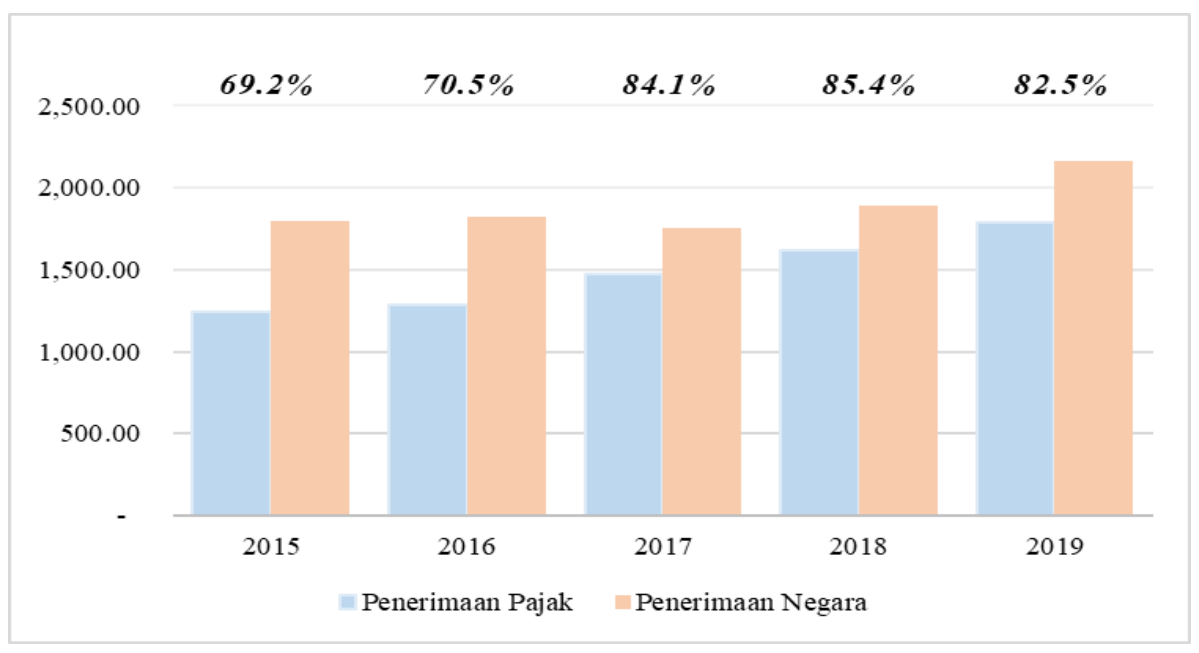

Gambar 2. Persentase Penerimaan Pajak terhadap Total Penerimaan tahun 2015 s.d. 2019 Sumber: Diolah dari Anwar et al. (2019)

Ketentuan perpajakan bagi pelaku UMKM dengan peredaran bruto dalam satu tahun tidak melebihi Rp4.800.000.000 (empat miliar delapan ratus juta rupiah) mengacu pada Peraturan Pemerintah Nomor 46 tahun 2013 tentang Pajak Penghasilan atas Penghasilan dari Usaha yang Diterima atau Diperoleh Wajib Pajak yang Memiliki Peredaran Bruto Tertentu. Akan tetapi, kepatuhan pelaku UMKM dalam memenuhi kewajiban perpajakannya dinilai masih rendah. Hal ini dibuktikan dengan kontribusi pajak sektor UMKM pada tahun 2016 yang hanya sebesar $0.33 \%$ dari total penerimaan pajak (Anwar et al., 2019). Oleh karena itu, pada tanggal 1 Juli 2018 pemerintah mencabut dan menggantikan peraturan tersebut dengan Peraturan Pemerintah Nomor 23 tahun 2018, yang selanjutnya dalam penelitian ini disebut dengan PP 23 tahun 2018. Perubahan 
yang paling menarik adalah turunnya tarif pajak dari $1 \%$ menjadi $0,5 \%$ dari jumlah penghasilan bruto.

Namun, disamping perubahan tarif pajak juga terdapat perbedaan-perbedaan lain antara PP 46 tahun 2013 dengan PP 23 tahun 2018. Beberapa perbedaan tersebut berpotensi menimbulkan adanya tax avoidance atau penghindaran pajak oleh wajib pajak. Penelitian Lingga (2006) menjelaskan bahwa setiap bentuk usaha mempunyai beban pajak penghasilan yang berbeda-beda. Oleh karena itu, perlu dilakukan adanya perencanaan pajak (tax planning) untuk memilih bentuk badan usaha guna meminimalkan beban pajak yang harus ditanggung. Tax planning menurut Larking (2005, dikutip dalam Slamet, 2007) dapat dipersamakan dengan tax mitigation (pengurangan pajak), yaitu usaha wajib pajak untuk meminimalkan beban pajak yang harus dibayar. Selain itu, Zain (2005, dikutip dalam Slamet, 2007) menambahkan adanya proses mendeteksi cacat teoritis dalam ketentuan perpajakan. Upaya tax planning sebagaimana dijelaskan di atas dapat dilakukan oleh wajib pajak secara legal (tax avoidance) maupun ilegal (tax evasion).

Tax avoidance sendiri merupakan bentuk penghindaran pajak dengan menuruti peraturan yang ada dengan memanfaatkan lubang-lubang atau celah-celah dalam undang-undang perpajakan (Mangoting, 1999; Darussalam, 2017). Lumbantoruan (1996, dikutip dalam Slamet, 2007) menambahkan bahwa tax avoidance merupakan cara yang legal dan tidak perlu merasa berdosa. Sementara, Suandy (2003, dikutip dalam Slamet, 2007) memberikan istilah tax avoidance merupakan tax affairs (rekayasa perpajakan).

Sedangkan pengelakan pajak atau tax evasion adalah suatu skema meminimalkan beban pajak dengan cara melanggar ketentuan perpajakan (ilegal), seperti dengan cara tidak melaporkan sebagian pendapatannya atau dengan memperbesar biaya secara fiktif (Darussalam, 2017). Lumbantoruan (1996, dikutip dalam Mangoting, 1999) juga mengemukakan hal yang sama. Selanjutnya, Arnold (2016) menjelaskan tax evasion juga bisa dilakukan dengan tidak mengungkapkan kekayaannya (nondisclosure) yang sesungguhnya, serta melalui tindakan penipuan yang dilakukan dengan sengaja (willful deceit). Oleh karena itu, tindakan tersebut merupakan tindakan melanggar hukum yang dilarang dan dapat dikenakan sanksi pidana Vanistendael (1997, dikutip dalam Slamet, 2007).

Hasil penelitian Wijaya \& Arumningtias (2021) menjelaskan bahwa salah satu potensi tax avoidance yang dapat terjadi adalah upaya profit shifting atau pengalihan penghasilan karena di dalam PP 23 tahun 2018 tidak ada klausul "satu tahun komersial" bagi wajib pajak badan, sehingga wajib pajak badan yang baru didirikan dapat langsung menggunakan tarif sesuai PP 23 tahun 2018. Upaya profit shifting dapat dilakukan oleh wajib pajak dengan mendirikan badan baru apabila peredaran brutonya telah mendekati Rp4.800.000.000 atau jangka waktu penggunaan PP 23 tahun 2018 telah berakhir dan mengalihkan penghasilannya kepada badan baru tersebut. Dengan demikian, wajib pajak tersebut tidak akan dikenai pajak penghasilan dengan tarif umum pajak penghasilan badan sebesar 25\%, melainkan tetap dikenakan tarif sesuai PP 23 tahun 2018. Upaya ini juga dikenal dengan istilah bunching.

Selain potensi yang telah dijelaskan sebelumnya, terdapat potensi tax avoidance lainnya yang akan dibahas dalam penelitian ini, yaitu mengenai pengecualian wajib pajak yang dapat menggunakan PP 23 tahun 2018. Dalam PP 23 tahun 2018, disebutkan bahwa wajib pajak yang dikenai pajak penghasilan final dengan tarif $0,5 \%$ dari peredaran bruto meliputi wajib pajak orang pribadi, koperasi, Persekutuan Komanditer (CV), firma, dan Perseroan Terbatas (PT) dengan peredaran bruto tidak melebihi Rp4.800.000.000 dalam satu tahun. Kemudian, pada pasal berikutnya dijelaskan mengenai pengecualian atas wajib pajak tersebut. Salah satu pengecualiannya adalah wajib pajak $\mathrm{CV}$ atau firma yang memperoleh penghasilan dari penyerahan jasa sehubungan dengan pekerjaan bebas. Namun, pasal tersebut tidak menyebutkan PT sebagai wajib pajak yang dikecualikan. Artinya, wajib pajak UMKM yang menyerahkan jasa sehubungan dengan pekerjaan bebas dengan bentuk usaha PT dapat menggunakan tarif sebesar $0,5 \%$, sedangkan bagi wajib pajak yang berbentuk $\mathrm{CV}$ atau firma harus menggunakan tarif umum pajak penghasilan badan sebesar $25 \%$.

PT menurut Purwosutjipto (1982, dikutip dalam Barkatullah, 2017), Perseroan Terbatas (PT) terdiri dari dua kata, yaitu "perseroan" dan "terbatas". Perseroan mempunyai arti bahwa struktur modal PT terdiri dari sero atau saham, sedangkan terbatas merujuk pada terbatasnya 
lingkup tanggung jawab pemegang saham, yakni hanya sebatas pada besarnya modal yang disetorkan ke dalam perusahaan. Selanjutnya, Widjaya ( n.d., dikutip dalam Nurnaningsih \& Solihin, 2020) berpendapat bahwa PT adalah persekutuan berbadan hukum yang merupakan kumpulan modal atau saham, kekayaannya terbagi atas para perseronya, tanggung jawab pemegang saham yang terbatas dan terpisah dengan tanggung jawab pengurus atau direksi, mempunyai komisaris yang merangkap sebagai pengawas, serta adanya Rapat Umum Pemegang Saham (RUPS) sebagai pemegang kekuasaan tertinggi. Sementara Suparji (2015) menyebutkan bahwa PT mempunyai beberapa unsur, yaitu kekayaan terpisah, adanya tujuan tertentu, mempunyai kepentingan sendiri dan organisasinya teratur.

Berdasarkan berbagai penjelasan di atas, maka penulis tertarik untuk melakukan penelitian terhadap potensi terjadinya tax avoidance bagi wajib pajak sektor UMKM yang menyerahkan jasa sehubungan dengan pekerjaan bebas, yaitu dengan lebih memilih untuk mendirikan PT dibanding CV atau firma, sehingga dapat menggunakan tarif pajak penghasilan final PP 23 tahun 2018 sebesar $0,5 \%$ yang relatif lebih rendah. Tujuan dari penelitian ini adalah untuk menjelaskan potensi tax avoidance PP 23 tahun 2018 yang dapat dilakukan oleh wajib pajak PT serta dampak dan solusi dari tindakan tax avoidance tersebut.

\section{STUDI LITERATUR}

Penelitian Lingga (2006) menjelaskan bahwa setiap bentuk usaha mempunyai beban pajak penghasilan yang berbeda-beda. Oleh karena itu, perlu dilakukan adanya perencanaan pajak (tax planning) untuk memilih bentuk badan usaha guna meminimalkan beban pajak yang harus ditanggung. Penelitian tersebut dilakukan terhadap tiga alternatif pilihan bentuk usaha yang meliputi usaha perorangan, persekutuan (CV), dan Perseroan Terbatas (PT). Berdasarkan hasil penelitiannya, bentuk usaha yang paling tepat untuk dapat meminimalkan beban pajak penghasilan adalah CV. Keuntungan dari bentuk usaha CV antara lain karena tarif pajak yang lebih rendah serta terhindar dari pajak berganda atas laba dan dividen.

Berdasarkan hasil penelitiannya, Mangoting (1999) menyimpulkan bahwa tax planning merupakan langkah yang penting untuk meminimalkan beban pajak. Dengan beban pajak yang lebih kecil, akan ada aliran kas (cash flow) yang dapat digunakan untuk keperluan lainnya. Proses tax planning sendiri dapat dilakukan dengan memahami formula umum dari tax planning. Selanjutnya, formula tersebut dianalisis dan dilakukan upaya tax planning dengan memanfaatkan celah undang-undang (loopholes) pada item-item tertentu untuk memperoleh beban pajak yang lebih kecil. Beberapa upaya tax planning yang dapat dilakukan antara lain dengan meningkatkan penghasilan yang dikecualikan dari objek pajak serta meningkatkan besarnya beban-beban fiskal.

Sementara itu, Wijaya dan Arumningtias (2021) menjelaskan bahwa perubahan PP 46 tahun 2013 menjadi PP 23 tahun 2018 menimbulkan berbagai perbedaan yang dapat menimbulkan adanya potensi tax avoidance. Potensi tax avoidance yang dapat terjadi adalah upaya profit shifting supaya tidak termasuk ke dalam jenis penghasilan yang dikenakan PP 23 tahun 2018. Profit shifting juga dapat dilakukan oleh wajib pajak badan apabila peredaran brutonya mendekati Rp4.800.000.000 atau pada saat batasan jangka waktu penggunaan PP 23 tahun 2018 telah berakhir, yaitu dengan mendirikan badan baru supaya dapat tetap menggunakan tarif PP 23 tahun 2018 tersebut.

\section{METODE}

Pengumpulan data dan informasi yang dibutuhkan dalam penelitian ini dilakukan dengan metode studi kepustakaan dan metode wawancara. Penulis mengumpulkan data dan informasi utama dari peraturan perundang-undangan terkait beserta aturan pelaksanaannya. Selain itu, informasi juga diperoleh dari beberapa literatur lain seperti buku, jurnal, dan berbagai sumber lain yang berkaitan dengan permasalahan penelitian. Sedangkan wawancara menggunakan narasumber yang mempunyai pengetahuan dan pengalaman dalam bidang perpajakan, yaitu NR, seorang pegawai Direktorat Jenderal Pajak, serta Ibu Hanik Susilawati Muamarah dan Bapak Benny Setiawan yang merupakan dosen Politeknik Keuangan Negara STAN. 
HASIL

Untuk menjawab berbagai penelitian tersebut, peneliti mengumpulkan berbagai data. Yang dimulai dari data sekunder yang berasal dari ketentuan perpajakan, yaitu Peraturan Pemerintah Nomor 46 Tahun 2013 yang telah diganti dengan Peraturan Pemerintah Nomor 23 Tahun 2018. Terkait dengan ketentuan perpajakan tersebut, diketahui bahwa dari penelitian terdahulu, bahwa untuk meminimalkan beban pajak, Mangoting (1999) menjelaskan bahwa perusahaan dapat melakukan tax planning. Tax planning yang dapat dilakukan, menurut penelitian Lingga (2006) bisa dimulai dari bentuk badan usaha itu sendiri. Terkait tax planning yang dilakukan dengan bentuk badan usaha ternyata terdapat dalam ketentuan Peraturan Pemerintah Nomor 23 Tahun 2018, dimana terdapat perbedaan terhadap penghasilan yang berhubungan dengan pekerjaan bebas, yaitu untuk CV dan Firma tidak diperkenankan. Sementara itu, untuk bentuk Perseoan Terbatas tidak dilarang terhadap penghasilan yang berhubungan dengan pekerjaan bebas. Data sekunder juga diperoleh dari hasil penelitian Wijaya dan Arumningtias (2021) yang menjelaskan bahwa perubahan PP 46 tahun 2013 menjadi PP 23 tahun 2018 menimbulkan berbagai perbedaan yang dapat menimbulkan adanya potensi tax avoidance. Namun demikian, penelitian Wijaya dan Arumningtias (2021) baru membahas ketentuan terkait wajib pajak baru yang boleh langsung menggunakan ketentuan Peraturan Pemerintah Nomor 23 Tahun 2018. Sehingga penelitian terkait penggunaan bentuk usaha Perseroan Terbatas yang dapat menjadikan potensi tax avoidance belum pernah dilakukan.

Untuk membahas berbagai tujuan penelitian, maka peneliti menggunakan data primer yang berasal dari narasumber dari Direktorat Jenderal Pajak dan dosen di Politeknik Keuangan Negara STAN. Selanjutnya dari data sekunder dan primer yang telah dikumpulkan, maka peneliti akan menggunakan triangulasi untuk merangkai pembahasan, sehingga diperoleh gambaran yang bisa menjelaskan tujuan penelitian.

\section{PEMBAHASAN}

Pada tanggal 1 Juli 2018, pemerintah mencabut PP 46 tahun 2013 dan menggantikannya dengan PP 23 tahun 2018 untuk mengubah ketentuan perpajakan bagi wajib pajak yang memiliki peredaran bruto tertentu. Perubahan ketentuan tersebut bertujuan untuk mendorong masyarakat supaya lebih berperan serta dalam kegiatan ekonomi formal, yakni dengan cara memberikan kemudahan dan keadilan kepada masyarakat, dalam hal ini adalah wajib pajak. Menurut ketiga narasumber, kebijakan tersebut dilatarbelakangi dengan tarif pajak PP 46 tahun 2013 sebesar 1\% dari penghasilan bruto yang dianggap terlalu tinggi bagi wajib pajak, sehingga diturunkan menjadi 0,5\% dari penghasilan bruto dengan PP 23 tahun 2018. Dengan tarif yang lebih rendah, diharapkan kepatuhan dan kontribusi wajib pajak semakin meningkat. Selanjutnya, Bapak Benny menambahkan bahwa penurunan tarif pajak tersebut juga berisiko menyebabkan penurunan penerimaan pajak dari wajib pajak yang sebelumnya telah memenuhi kewajiban perpajakannya. Akan tetapi, risiko tersebut dapat diatasi melalui pengalihan ke jenis pajak atau wajib pajak yang lain. Contohnya adalah peningkatan penerimaan PPN seiring dengan peningkatan konsumsi masyarakat, meningkatnya penerimaan pajak daerah seperti Pajak Hotel dan Pajak Restoran, serta bertambahnya jumlah wajib pajak PP 23 tahun 2018 yang turut memberikan kontribusinya karena adanya penurunan tarif pajak.

Perubahan PP 46 tahun 2013 menjadi PP 23 tahun 2018 menimbulkan adanya perubahan ketentuan perpajakan yang ada. Menurut ketiga narasumber, perubahan yang paling mencolok adalah penurunan tarif pajak dari $1 \%$ menjadi $0,5 \%$ dari penghasilan bruto. Selain itu, terdapat pula perubahan mengenai wajib pajak PP 23 tahun 2018 dengan batasan jangka waktu penggunaannya, serta adanya perubahan objek pajak PP 23 tahun 2018 dan pengecualiannya. Adapun untuk CV dan Firma dapat menggunakan ketentuan ini empat tahun sejak tahun 2018 atau sejak perusahaan didirikan. Sedangkan untuk Perseroan Terbatas hanya dapat menggunakan ketentuan ini tiga tahun sejak tahun 2018 atau sejak perusahaan didirikan. Di samping itu, Ibu Hanik menambahkan bahwa terdapat pula perubahan mengenai ketentuan penggunaan PP 23 tahun 2018 yang bersifat opsional.

Perubahan-perubahan tersebut secara umum memberikan dampak positif bagi wajib pajak. Ketiga narasumber berpendapat bahwa perubahan tarif pajak dari $1 \%$ menjadi $0,5 \%$ dari penghasilan bruto akan meminimalkan beban pajak yang harus ditanggung oleh wajib pajak, 
sehingga wajib pajak diharapkan akan lebih tertarik untuk memenuhi kewajiban perpajakannya. Selanjutnya, menurut pendapat Ibu Hanik, adanya jangka waktu penggunaan PP 23 tahun 2018 akan memaksa wajib pajak untuk kembali menggunakan tarif umum pajak penghasilan setelah jangka waktu penggunaannya berakhir, dimana wajib pajak yang melakukan kegiatan usaha diwajibkan untuk melaksanakan pembukuan. Hal tersebut secara implisit berperan dalam memberikan edukasi kepada wajib pajak bahwa pembukuan merupakan hal yang penting bagi wajib pajak, sehingga wajib pajak diharuskan untuk belajar mengenai penyusunan laporan keuangan yang akan bermanfaat untuk wajib pajak itu sendiri. Selain itu, Ibu Hanik juga menjelaskan bahwa ketentuan penggunaan PP 23 tahun 2018 yang bersifat opsional juga memberikan dampak positif, yaitu berupa keadilan bagi wajib pajak. Sebelumnya, PP 46 tahun 2013 mengharuskan seluruh wajib pajaknya untuk menggunakan tarif sebesar $1 \%$ dari penghasilan bruto. Namun, terdapat beberapa wajib pajak yang keberatan dengan tarif yang dikalikan langsung dari penghasilan bruto (omzet) tersebut karena keuntungan yang diperoleh sangat kecil jika dibandingkan dengan omzetnya. Dengan diberlakukannya PP 23 tahun 2018 yang penggunaannya bersifat opsional, wajib pajak dapat memilih untuk menggunakan tarif sesuai dengan PP 23 tahun 2018 maupun menggunakan tarif umum pajak penghasilan, sehingga wajib pajak dapat menanggung beban pajak yang lebih kecil.

\section{Potensi Tax Avoidance PP 23 tahun 2018 oleh Wajib Pajak PT}

Meskipun perubahan ketentuan perpajakan yang terjadi akibat diberlakukannya PP 23 tahun 2018 secara umum memberikan dampak positif, hal tersebut juga menimbulkan dampak negatif, khususnya bagi penerimaan negara. Dampak negatif tersebut berupa potensi terjadinya tindakan tax avoidance oleh wajib pajak. Sebagaimana telah dijelaskan dalam penelitian Wijaya \& Arumningtias (2021), salah satu potensi tax avoidance yang dapat terjadi adalah upaya profit shifting atau pengalihan penghasilan karena di dalam PP 23 tahun 2018 tidak ada klausul "satu tahun komersial" bagi wajib pajak badan, sehingga wajib pajak badan yang baru didirikan dapat langsung menggunakan tarif sesuai PP 23 tahun 2018. Upaya profit shifting dapat dilakukan oleh wajib pajak dengan mendirikan badan baru apabila peredaran brutonya telah mendekati Rp4.800.000.000 dan mengalihkan penghasilannya kepada badan baru tersebut. Dengan demikian wajib pajak tidak akan dikenai Pajak Penghasilan dengan tarif umum Pajak Penghasilan, melainkan tetap dikenakan tarif sesuai PP 23 tahun 2018 yang tarif pajaknya relatif lebih rendah. Upaya profit shifting tersebut juga dapat terjadi dalam hal jangka waktu penggunaan PP 23 tahun 2018 oleh wajib pajak telah berakhir.

Selain itu, terdapat potensi tindakan tax avoidance lain yang dapat terjadi, yaitu terkait dengan ketentuan pengecualian wajib pajaknya. Dalam Pasal 3 ayat (1) PP 23 tahun 2018, disebutkan bahwa wajib pajak yang dikenai Pajak Penghasilan final dengan tarif $0,5 \%$ dari peredaran bruto meliputi wajib pajak orang pribadi, koperasi, CV, firma, dan PT dengan peredaran bruto dalam satu tahun tidak melebihi Rp4.800.000.000. Kemudian, pada Pasal 3 ayat (2) dijelaskan mengenai pengecualian atas wajib pajak tersebut. Salah satu pengecualiannya adalah wajib pajak $\mathrm{CV}$ atau firma yang memperoleh penghasilan dari penyerahan jasa sehubungan dengan pekerjaan bebas. Akan tetapi, pasal tersebut tidak menyebutkan PT sebagai wajib pajak yang dikecualikan dari penggunaan PP 23 tahun 2018. Artinya, wajib pajak berbentuk PT yang menyerahkan jasa sehubungan dengan pekerjaan bebas dapat menggunakan tarif PP 23 tahun 2018 sebesar 0,5\%, sedangkan bagi wajib pajak yang berbentuk $\mathrm{CV}$ atau firma harus menggunakan tarif umum pajak penghasilan sebesar $25 \%$. Hal tersebut tentunya menjadi suatu celah bagi wajib pajak untuk melakukan tindakan tax avoidance untuk dapat menggunakan tarif yang relatif lebih rendah.

Berdasarkan pendapat dari ketiga narasumber, tindakan tax avoidance yang dapat terjadi karena adanya celah dalam pengecualian wajib pajak PP 23 tahun 2018 tersebut berupa pemilihan bentuk usaha. Wajib pajak yang bergerak dalam penyerahan jasa sehubungan dengan pekerjaan bebas yang berniat untuk mendirikan badan usaha akan memperkirakan terlebih dahulu besarnya omzet (penghasilan bruto) dan keuntungan yang akan diperolehnya. Apabila wajib pajak memperoleh persentase keuntungan yang cukup besar dari nilai omzetnya, artinya wajib pajak tersebut akan merasa bahwa tarif PP 23 tahun 2018 sebesar 0,5\% dari penghasilan bruto merupakan tarif yang cukup ringan. Akibatnya, wajib pajak akan berupaya untuk dapat menggunakan tarif 
tersebut supaya beban pajak yang ditanggungnya menjadi lebih kecil. Upaya tersebut dapat dilakukan oleh wajib pajak dengan cara memilih untuk mendirikan PT dibandingkan dengan CV atau firma. Dengan mendirikan PT, wajib pajak dapat menggunakan PP 23 dengan tarif 0,5\% dari penghasilan bruto, sedangkan jika mendirikan $\mathrm{CV}$ atau firma harus menggunakan tarif umum pajak penghasilan badan karena CV dan firma yang menyerahkan jasa sehubungan dengan pekerjaan bebas merupakan salah satu wajib pajak yang dikecualikan dari penggunaan PP 23 tahun 2018.

Selanjutnya, dalam perkembangan terbaru telah diterbitkan Undang-Undang Nomor 11 tahun 2020 tentang Cipta Kerja pada tanggal 2 November 2020 dengan tujuan untuk memberikan kemudahan usaha bagi masyarakat. Namun, Bapak NR dan Bapak Benny menganggap bahwa diterbitkannya Undang-Undang Cipta Kerja juga berdampak pada potensi tax avoidance PP 23 oleh wajib pajak PT sebagaimana telah dijelaskan sebelumnya. Salah satu topik yang dibahas dalam Undang-Undang Cipta Kerja adalah perubahan beberapa ketentuan dalam Undang-Undang Perseroan Terbatas. Salah satu perubahannya yaitu mengenai ketentuan pendirian PT yang memenuhi kriteria Usaha Mikro dan Kecil (UMK). Sebelumnya, suatu PT yang memenuhi kriteria UMK harus didirikan oleh dua orang atau lebih menggunakan akta notaris. Namun, pada UndangUndang Cipta Kerja dijelaskan bahwa PT yang memenuhi kriteria UMK tersebut dapat didirikan oleh satu orang menggunakan surat pernyataan pendirian. Perubahan tersebut tentunya akan mempermudah pendirian PT bagi pengusaha sektor UMK. Dengan kemudahan tersebut, maka potensi terjadinya tindakan tax avoidance oleh wajib pajak yang akan mendirikan badan usaha menjadi semakin besar, karena pendirian PT yang memenuhi kriteria UMK menjadi lebih mudah dibandingkan dengan pendirian $\mathrm{CV}$ atau firma.

Meskipun demikian, tindakan tax avoidance pada dasarnya kembali kepada niat wajib pajak yang bersangkutan, apakah berniat untuk memberikan kontribusi kepada negara atau akan menggunakan celah yang ada di dalam ketentuan perpajakan. Menurut Bapak NR dan Ibu Hanik, wajib pajak PP 23 tahun 2018 sendiri sebenarnya tidak terlalu berpotensi untuk melakukan tindakan tax avoidance karena rata-rata pengetahuan perpajakan yang dimilikinya cukup rendah, sehingga wajib pajak kurang mengetahui celah-celah yang ada di dalam PP 23 tahun 2018. Namun, tidak sedikit pula wajib pajak PP 23 tahun 2018 yang memiliki pengetahuan perpajakan yang cukup memadai. Bapak Benny berpendapat bahwa sebagian dari wajib pajak tersebut mungkin telah memiliki pengetahuan perpajakan yang memadai, tetapi tidak disertai dengan kesadaran dan kepatuhan pajak yang tinggi, sehingga wajib pajak tersebut berpotensi melakukan tindakan tax avoidance untuk meminimalkan beban pajaknya. Selain itu, Bapak NR menambahkan bahwa potensi tindakan tax avoidance juga dapat disebabkan dengan adanya wajib pajak PP 23 tahun 2018 yang menggunakan jasa konsultan pajak dalam memenuhi kewajiban perpajakannya. Konsultan pajak yang mempunyai pengetahuan perpajakan yang memadai dapat dimanfaatkan oleh wajib pajak untuk melakukan tindakan tax avoidance demi meminimalkan beban pajaknya. Berdasarkan penjelasan tersebut, penulis menyimpulkan bahwa meskipun rata-rata pengetahuan perpajakan wajib pajak PP 23 tahun 2018 masih cukup rendah, hal tersebut tidak menutup kemungkinan terjadinya tindakan tax avoidance oleh wajib pajak.

\section{Dampak Tax Avoidance PP 23 tahun 2018 oleh Wajib Pajak PT}

Celah yang ada di dalam PP 23 tahun 2018 terkait dengan pengecualian CV dan firma yang menyerahkan jasa sehubungan dengan pekerjaan bebas untuk menggunakan PP 23 tahun 2018 dapat dimanfaatkan oleh wajib pajak untuk melakukan tindakan tax avoidance. Wajib pajak akan memilih untuk mendirikan badan dengan bentuk PT dibandingkan dengan CV atau firma karena dapat menggunakan PP 23 tahun 2018 dengan tarif pajak yang relatif lebih rendah, sehingga beban pajak yang ditanggungnya menjadi lebih kecil. Dari sudut pandang wajib pajak, hal tersebut merupakan suatu keuntungan. Namun, dari sudut pandang DJP, hal tersebut merupakan suatu kerugian. Wajib pajak badan yang seharusnya dapat dikenakan tarif umum pajak penghasilan badan sebesar 25\% dari Penghasilan Kena Pajak justru menggunakan tarif PP 23 tahun 2018 sebesar 0,5\% dari penghasilan bruto. Akibatnya, terdapat potensi pajak yang hilang sehingga penerimaan pajak berkurang.

Meskipun demikian, Bapak NR menyatakan bahwa tindakan tax avoidance tersebut merupakan salah satu langkah wajib pajak untuk meminimalisasi pengeluaran pajaknya yang 
dilakukan dengan cara memanfaatkan celah yang ada di dalam PP 23 tahun 2018, bukan dengan melanggar peraturan tersebut. Selama tidak ada peraturan yang membatasi tindakan tax avoidance, maka tindakan tersebut merupakan tindakan yang legal. Oleh karena itu, meskipun tindakan tax avoidance tersebut menyebabkan berkurangnya penerimaan pajak, tindakan tersebut tidak dapat ditindaklanjuti dengan upaya hukum oleh DJP. Upaya yang dapat dilakukan oleh DJP untuk mengatasi hal tersebut terbatas pada upaya penggalian potensi pada sektor lainnya. Pendapat serupa juga disampaikan oleh Bapak Benny, yaitu bahwa terhadap suatu tindakan tax avoidance, DJP tidak dapat melakukan upaya hukum, melainkan hanya dapat melakukan upaya pencegahan dan pengawasan.

Mengingat tindakan tax avoidance terhadap PP 23 tahun 2018 oleh wajib pajak PT tersebut berakibat pada berkurangnya penerimaan pajak, maka pemerintah dalam hal ini DJP perlu memperhatikan hal tersebut. Celah-celah yang ada dalam PP 23 tahun 2018 perlu untuk diperbaiki supaya potensi terjadinya tindakan tax avoidance dapat diminimalisasi. Menurut ketiga narasumber, beberapa upaya yang dapat dilakukan oleh DJP untuk meminimalisasi adanya potensi tax avoidance terhadap PP 23 tahun 2018 tersebut antara lain:

\section{Edukasi dan penyuluhan kepada wajib pajak}

Berdasarkan pendapat Bapak Benny, DJP sebaiknya melakukan edukasi atau penyuluhan kepada masyarakat, khususnya kepada wajib pajak PP 23 tahun 2018. Tujuannya adalah untuk memberikan pengetahuan kepada wajib pajak mengenai ketentuan yang terdapat di dalam PP 23 tahun 2018. Edukasi atau penyuluhan tersebut merupakan hal yang sangat penting, karena dengan pengetahuan yang dimilikinya, wajib pajak dapat mempunyai kesadaran dan kepatuhan pajak yang lebih tinggi, sehingga potensi terjadinya tindakan tax avoidance menjadi lebih kecil.

\section{Pengawasan wajib pajak}

Pengetahuan yang diperoleh wajib pajak dari proses edukasi dan penyuluhan oleh DJP terkadang tidak disertai dengan meningkatnya kesadaran dan kepatuhan wajib pajak untuk memenuhi kewajiban perpajakannya. Mereka justru menggunakan pengetahuan tersebut untuk mencari celah-celah yang ada dalam peraturan perpajakan, salah satunya seperti celah di dalam PP 23 tahun 2018 terkait pengecualian wajib pajaknya sebagaimana telah dijelaskan sebelumnya. Dalam kasus tersebut, maka wajib pajak berpotensi untuk melakukan tindakan tax avoidance. Oleh karena itu, Bapak Benny berpendapat bahwa DJP perlu untuk meningkatkan mekanisme pengawasan terhadap tindakan-tindakan wajib pajak supaya dapat meminimalisasi terjadinya tax avoidance terhadap PP 23 tahun 2018 tersebut, khususnya terhadap wajib pajak PT yang menggunakan PP 23 tahun 2018. Dalam peningkatan mekanisme pengawasan tersebut, Ibu Hanik menambahkan bahwa diperlukan pula adanya komunikasi yang baik dengan unit atau pihak yang berinteraksi langsung dengan wajib pajak untuk mengetahui tindakan tax avoidance terhadap PP 23 tahun 2018 yang terjadi di lapangan.

\section{Evaluasi dan perbaikan regulasi}

Menurut Ibu Hanik, upaya selanjutnya yang dapat dilakukan oleh DJP untuk meminimalisasi potensi tax avoidance adalah dengan melakukan evaluasi terhadap pelaksanaan PP 23 tahun 2018. Berdasarkan basis data yang dimilikinya, DJP dapat melihat perkembangan jumlah wajib pajak PT yang menggunakan PP 23 tahun 2018 pada saat sebelum dan setelah diberlakukannya ketentuan tersebut. DJP juga dapat melakukan sampling terhadap wajib pajak PT yang menggunakan PP 23 tahun 2018 untuk mengetahui alasan pendirian PT, apakah untuk tujuan tax avoidance atau tujuan lain.

Selanjutnya, DJP dapat melakukan evaluasi terhadap pelaksanaan PP 23 tahun 2018 menggunakan data dan informasi yang telah diperoleh. Apabila hasil evaluasi menunjukkan bahwa pelaksanaan PP 23 tahun 2018 masih berjalan efektif, maka pelaksanaan ketentuan tersebut dapat tetap dilanjutkan. Namun, apabila hasilnya tidak efektif, artinya ketentuan tersebut perlu dilakukan perbaikan dan penyempurnaan supaya celah bagi wajib pajak untuk melakukan tindakan tax avoidance semakin kecil. 
Apabila diperlukan perbaikan dan penyempurnaan ketentuan dalam PP 23 tahun 2018, maka harus dilakukan pembahasan yang mendalam dalam penyusunan peraturan yang baru tersebut. Bapak NR memberikan pendapat bahwa penyusunan peraturan dapat dilakukan dengan melakukan kerja sama antar kementerian. Dengan kerja sama antar kementerian, diharapkan peraturan dapat saling menguatkan dari berbagai sisi, termasuk salah satunya dari sisi perpajakan yaitu potensi terjadinya tax avoidance. Sebagai contoh, diberlakukannya Undang-Undang Cipta Kerja yang bertujuan untuk mempermudah masyarakat melakukan usaha, justru memperbesar celah tax avoidance PP 23 tahun 2018 oleh wajib pajak PT. Oleh karena itu, kerja sama antar pemerintah dalam melakukan perbaikan dan penyempurnaan PP 23 tahun 2018 merupakan hal yang sangat penting untuk meminimalisasi potensi terjadinya tax avoidance.

\section{KESIMPULAN}

Dengan berlakukannya PP 23 tahun 2018 untuk menggantikan PP 46 tahun 2013 menyebabkan adanya beberapa perubahan ketentuan bagi wajib pajaknya. Sebagian dari perubahan-perubahan tersebut berdampak pada timbulnya celah bagi wajib pajak untuk melakukan tindakan tax avoidance. Salah satu celah yang dimaksud adalah tidak adanya pengecualian bagi wajib pajak badan berbentuk PT yang menyerahkan jasa sehubungan dengan pekerjaan bebas untuk menggunakan PP 23 tahun 2018, melainkan hanya CV dan firma. Celah tersebut dapat dimanfaatkan oleh wajib pajak yang akan mendirikan badan usaha dengan lebih memilih mendirikan PT dibandingkan dengan CV atau firma supaya dapat menggunakan tarif PP 23 tahun 2018 yang relatif lebih rendah. Meskipun jika dilihat dari sisi wajib pajak PP 23 tahun 2018, potensi terjadinya tindakan tax avoidance tersebut tidak terlalu besar, hal tersebut tetap perlu menjadi perhatian bagi DJP, karena tindakan tax avoidance berakibat pada berkurangnya penerimaan pajak. Oleh karena itu, DJP perlu melakukan upaya-upaya untuk meminimalisasi potensi terjadinya tindakan tax avoidance tersebut. Beberapa upaya yang dapat dilakukan antara lain dengan melakukan edukasi kepada wajib pajak untuk meningkatkan kesadaran dan kepatuhan pajak, meningkatkan mekanisme pengawasan terhadap tindakan-tindakan wajib pajak yang berpotensi melakukan tax avoidance, serta melakukan perbaikan dan penyempurnaan PP 23 tahun 2018 apabila pelaksanaannya kurang efektif.

\section{REFERENSI}

Anwar, A. A., Bawadi, Hastiwi, H., Mahayasa, R. S., Hasibuan, M. A. Y., Zalasyani, F., Purnomo, D. D., Avian, Y. B., \& Ciptadi, A. M. (2019). Workshop UMKM Patriot Untuk Negeri.

Arnold, B. J. (2016). International Tax Primer: Third Edition. Kluwer Law International B.V.

Barkatullah, A. H. (2017). Hukum Perseroan di Indonesia. Nusa Media.

Darussalam. (2017). Perencanaan Pajak: Ini Beda Tax Planning, Tax Avoidance, dan Tax Evasion. https://news.ddtc.co.id/perencanaan-pajak-ini-beda-tax-planning-tax-avoidance-dan-taxevasion-9750

Darussalam, D. (2020). Siapa Saja yang Seharusnya Menjadi Subjek Pajak. https://news.ddtc.co.id/siapa-saja-yang-seharusnya-menjadi-subjek-pajak-18836

Darussalam, Septriadi, D., \& Dhora, K. A. (2020). Konsep dan Aplikasi Pajak Penghasilan. DDTC.

Lingga, I. S. (2006). Analisis Pemilihan Bentuk Usaha yang Tepat: Suatu Upaya dalam Meminimalkan Beban Pajak Penghasilan. Jurnal Ilmiah Akuntansi, V(2), 37-46. https://doi.org/https://doi.org/10.28932/jam.v5i2.278

Mangoting, Y. (1999). Tax Planning: Sebuah Pengantar Sebagai Alternatif Meminimalkan Pajak. Jurnal Akuntansi Dan Keuangan, 1(1), 43-53. https://doi.org/10.9744/jak.1.1.pp.43-53

Mustaqiem, M. (2014). Perpajakan dalam Konteks Teori dan Hukum Pajak di Indonesia. Buku Litera Yogyakarta.

Nurnaningsih, R., \& Solihin, D. (2020). Badan hukum perseroan ditinjau menurut Undang-Undang Perseroan Terbatas (UUPT) dan Nieuw Burgerlijk Wetboek (NBW) di era bisnis digital. Syntax Idea, 2(4), 111-124. https://doi.org/10.36418/syntax-idea.v2i4.197

Profil Bisnis Usaha Mikro, Kecil dan Menengah (UMKM). (2015). Bank Indonesia.

Republik Indonesia. (2007). Undang-Undang Republik Indonesia Nomor 40 tahun 2007 tentang Perseroan Terbatas. Jakarta: Sekretariat Negara. 
Owner: Riset \& Jurnal Akuntansi

e-ISSN : 2548-9224 |p-ISSN : 2548-7507

Volume 5 Nomor 2, Agustus 2021

Republik Indonesia. (2008). Undang-Undang Republik Indonesia Nomor 20 tahun 2008 tentang Usaha Mikro, Kecil, dan Menengah. Jakarta: Sekretariat Negara.

Republik Indonesia. (2013). Peraturan Pemerintah Republik Indonesia Nomor 46 tahun 2013 tentang Pajak Penghasilan atas Penghasilan dari Usaha yang Diterima atau Diperoleh Wajib Pajak yang Memiliki Peredaran Bruto Tertentu. Jakarta: Sekretariat Negara.

Republik Indonesia. (2018). Peraturan Pemerintah Republik Indonesia Nomor 23 tahun 2018 tentang Pajak Penghasilan atas Penghasilan dari Usaha yang Diterima atau Diperoleh Wajib Pajak yang Memiliki Peredaran Bruto Tertentu. Jakarta: Sekretariat Negara.

Republik Indonesia. (2020). Undang-Undang Republik Indonesia Nomor 11 tahun 2020 tentang Cipta Kerja. Jakarta: Sekretariat Negara.

Slamet, I. (2007). Tax planning, tax avoidance, dan tax evasion di mata perpajakan Indonesia. 8 10.

Suparji, S. (2015). Transformasi Badan Hukum di Indonesia. UAI Press.

Widyana, I. W. (2018). Perpajakan. CV. Noah Aletheia.

Wijaya, S., \& Arumningtias, D. (2021). Preventing the Potential Tax Avoidance in Government Regulation of the Republic of Indonesia Number 23 of 2018. Multicultural Education, 7(1), 288-301. https://doi.org/10.5281/zenodo.4515858 